\title{
SISTEM PEMBINAAN HALAQAH TERHADAP KECERDASAN EMOSIONAL SANTRI DI MARKAZ TAHFIDZ ALQURAN AL-BIRR
}

\author{
Ahmad Nashir ${ }^{1}$, Abdul Halib ${ }^{2}$ \\ ${ }^{* 1}$ Pendidikan Agama Islam Fakultas Agama Islam| Unismuh Makassar \\ ${ }^{* 2}$ Pendidikan Agama Islam Fakultas Agama Islam| Unismuh Makassar
}

\begin{abstract}
ABSTRAK
Tujuan penelitian ini adalah untuk mengetahui kualitas daya ingat hafalan quran pondok pesantren dan emosional quetient para alumni setelah kembali kemasyarakat"dan untuk mengetahui Penelitian ini adalah merupakan penelitian (Field Research). Metode penelitian yang digunakan adalah dengan menggunakan metode pengumpulan data yang digunakan dengan jalan mengadakan penelitian secara langsung kelokasi yang menjadi tempat penelitian. Untuk melengkapi data penelitian digunakan instrnment penelitian observasi, wawancara, dokumentasi, sehingga data terkumpul dan dianalisis. Hasil penelitian menunjukkan bahwa, "Sistem Pembinaan Halaqah di Markaz Tahfidz Alquran Al-birr sudah diterapkan dan sudah menjadi program tahfidz Al-birr Malino yang diterapkan sejak dulu dan berjalan sampai saat ini" dimana dalam sistem pembinaan dalam menghafal Alquran yaitu, "sistem tahsin, sistem privat dan sistem mandiri" dan "faktor-faktor yang mendukung yaitu, mampu memahami ilmu tajwid dan mudah melafaskannya, kemauan santri itu sendiri, berkat dorongan dan motivasi orangtua, serta tidak jauh dari bimbingan ustdaz/pembina tahfidz"
\end{abstract}

\section{Kata Kunci: Pembinaan Halaqah, Kecerdasan Emosional}

\section{ABSTRACT}

The purpose of this study is to investigate the recall memorizing the Quran of students at boarding school and graduated emotional quotient after returning the society "and to know it. This is a research study (Field Research). The method used is to use the data collection methods used to conduct the research directly to location as the place to study. To complement the research data used instrument observational studies, interviews, documentation, so that the data is collected and analyzed. The results showed that the "System Development Halaqah in Markaz Tahfidz Qur'an Albirr has been implemented and is already a program Tahfidz Al-birr Malino applied since the first and walked up to the moment" in which the coaching system in memorizing the Qur'an that, "the system tahsin, system of private and self-contained system "and" the factors that support that is, able to understand the science of tajwid and easy to pronounce it, the willingness of the students themselves, thanks to the encouragement and motivation of parents, and not far from the guidance ustdaz I builder Tahfidz"

Keywords: Halaqah Coaching, Emotional Intelligenc 


\section{PENDAHULUAN}

Pendidikan merupakan sebuah media sosial tempat para peserta didik melakukan kegiatan interaksi sesama teman sebaya, dan merupakan salah satu media pembelajaran serta pengembangan sikap.

Samsul Nisar (2007:5-6) mengatakan bahwa penerapan sistem pembinaan halaqah atau pola pendidikan yang dilakukan oleh Rasulullah yaitu dengan tiga tahap.Tahap pertama adalah tahap rahasia dan perseorangan yaitu sejak turunnya wahyu yang pertama, pada ayat Alquran (Q.S. Al-Alaq (96) : 1-5). Tahap kedua adalah tahap terangterangan yaitu berselang tiga tahun sampai turunnya wahyu berikutnya, yang memerintahkan dakwah secara terbuka dan terang-terangan. Tahap ketiga adalah tahap untuk umum yaitu seruan dalam skala internasional tersebut, didasarkan kepada perintah Allah.

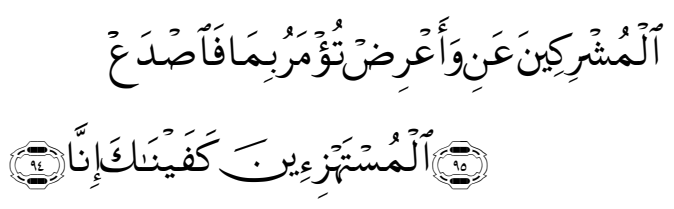

Terjemahnya :

Maka sampaikanlah olehmu secara terang-terangan segala apa yang di perintahkan (kepadamu) dan berpalinglah dari orang-orang yang musyrik, Sesungguhnya Kami memelihara kamu daripada (kejahatan) orang-orang yang memperolok-olokkan kamu”. (Q.S.Al-Hijr (15) : 94-95).

Sebagai tindak lanjut dari perintah tersebut, Pada musim haji Rasulullah mendatangi kemah para jemaah haji. Pada awalnya tidak banyak yang menerima, kecuali kelompok jemaah haji dari Yastrib, yang menerima dakwah secara antusias. Dari sinilah sinar Islam memancar keluar Mekkah.

Kita semua menyadari bahwa dari dulu proses pendidikan dan pembelajaran di Indonesia lebih berorientasi dan menekankan pada kemampuan intelektual (IQ) atau aspek kognisi saja. Pendidikan di Indonesia selama ini terlalu menekankan arti penting nilai akademik, kecerdasan otak atau IQ saja.

Guru khususnya Guru Pendidikan Agama Islam melakukan kegiatan bimbingan pengajaran secara sadar terhadap peserta didik untuk mencapai tujuan Pendidikan Islam. Pada kenyataannya, guru dalam menyampaikan pokok keagamaan hanya mampu menjadikan peserta didik memahami materi pokok yang diajarkan tanpa mengamalkannya dalam kehidupan sehari-hari.

Selain itu kecerdasan emosi juga menunjuk pada suatu kemampuan untuk memahami perasaan diri masingmasing dan perasaan orang lain, kemampuan memotivasi dirinya sendiri dan menata dengan baik emosiemosi yang muncul dalam dirinya serta dalam berhubungan dengan orang lain. Oleh karena itu, kecerdasan emosional juga sangat penting karena dapat membantu peserta didik atau santri dalam mengatur dan mengontrol diri dalam bersikap. Hal ini terdapat pada (Q.S. An-Naziat (79) : 40-41).

Menurut penelitian, IQ hanya berperan dalam kehidupan manusia dengan besaran maksimum 20\%, sehingga kecerdasan emosional memiliki peranan penting menentukan keberhasilan seseorang. 
Menurut penelitian dari Daniel Goleman seorang psikolog dari Harvard University bahwa IQ akan dapat bekerja secara efektif apabila seseorang mampu memfungsikan EQnya.

Seorang guru/ustadz pun harus mampu memiliki peran untuk membentuk karakter dan pribadi anak didiknya. Peserta didik yang memiliki kecerdasan emosional baik tentunya sangat berpengaruh dalam hubungan interpersonal diantara mereka. Hubungan interpersonal yang sudah terbangun akan sangat bermanfaat untuk menanamkan kerja sama antara siswa dalam mengatasi persoalan yang diberikan oleh guru.

Berdasarkan latar belakang di atas, maka rumusan masalah yang disusun adalah:

1. Bagaimana sistem pembinaan Halaqah bagi Santri di Markaz Tahfizh Alquran Albirr Kelurahan Malino Kecamatan Tinggi Moncong Kabupaten Gowa.?

2. Faktor-faktor apakah yang mendukung dan menghambat system pembinaan Halaqah dan kecerdasan emosional santri di Markaz Tahfizh Alquran Albirr Kelurahan Malino Kecamatan Tinggi Moncong Kabupaten Gowa.?

3. Adakah pengaruh sistem pembinaan Halaqah terhadap kecerdasan emosional Santri di Markaz Tahfizh Alquran Albirr Kelurahan Malino Kecamatan Tinggi Moncong Kabupaten Gowa.?

\section{METODE PENELITIAN}

Penelitian ini adalah penelitian lapangan, yaitu peneliti melakukan penelitian lapangan ke lokasi untuk mendapat dan mengumpulkan datadata. Penelitian ini bersifat deskriptif kualitatif dan data-data yang sehubungan dengan angka-angka, penulis mempergunakan analisis kuantitatif.

Penelitian ini dilakukan di Markaz Tahfidz Alquran Al-birr Kelurahan Malino Kecamatan Tinggi Moncong Kabupaten Gowa, dan objek penelitian, adalah para santri. Adapun instrumen yang digunakan dalam pengumpulan data di lapangan sesuai dengan obyek pembahasan penelitian ini adalah observasi, wawancara, dokumentasi dan bentuk instrumen penelitian tersebut digunakan karena pertimbangan praktis bahwa kemungkinan hasil akan valid.

Dalam pengumpulan data, secara garis besar peneliti akan menggunakan beberapa teknik sebagai berikut :

1. Observasi, yaitu melakukan pengamatan secara langsung pada objek penelitian dan mengumpulkan data yang diperlukan.

2. Wawancara, yaitu melakukan tanya jawab dengan pimpinan pondok tahfidz, guru/ustadz dalam mendapatkan data yang diperlukan.

3. Dokumentasi yaitu, informasi yang diperoleh lewat fakta yang tersimpan dalam surat, catatan harian, arsip dll.

$$
\text { Analisis data dalam }
$$
penelitian kualitatif dilakukan sejak sebelum memasuki lapangan, selama dilapangan, dan setelah selesai dilapangan. Aktivitas dalam analisis data meliputi: 
1. Reduksi data (data reduction) yang berarti merangkum, memilih hal-hal yang pokok, memfokuskan pada hal-hal penting, dicari tema dan polanya.

2. Penyajian data (data display) dalam penelitian ini penyajian data dilakukan dalam bentuk uraian singkat, bagan, hubungan antara kategori, flowchart dan sejenisnya, tetapi yang sering dipakai adalah dengan teks yang bersifat naratif.

3. Verification atau penarikan kesimpulan, teknik ini merupakan rangkaian analisis data puncak, dan kesimpulan membutuhkan verifikasi selama penelitian berlangsung.

\section{HASIL DAN PEMBAHASAN}

\section{A. Sistem Pembinaan Halaqoh Markas Tahfidz Al-Birr}

\section{Sistem Tahsin}

Berdasarkan dari hasil wawancara yang peneliti lakukan oleh ustadz/ Pembina tahfidz Alquran Albirr Malino bahwa: Sistem Pembinaan halaqah atau tahsin yaitu perbaikan bacaan sistem ini adalah perbaikan bacaan sebelum menghafal Qur'an selama satu bulan penuh dan santri tidak di perbolehkan menghafal Alquran sebelum sistem tahsin (Wawancara Ustadz Syarifuddin 25 Juni 2016).

Berdasarkan pemaparan diatas menjelaskan bahwa sistem tahsin merupakan perbaikan bacaan sebelum santri diperbolehkan menghafal Alquran, sistem ini santri baru diperbolehkan manghafal Alquran ketika santri sudah melewati sistem tahsin atau perbaikan bacaan dan bisa memahami hukum tajwaid fasih dalam Alquran.

Sedangkan hasil wawancara kepada santri yang dilakukan oleh peneliti dimana santri mengatakan bahwa: dengan adanya sistem tahsin santri lebih memahami bahwa mengahafal Alquran itu dibutuhkan tekad dan keberanian yang kuat, niat yang tulus bahwa menghafal Alquran, bukan hanya sekedarnya menghafal saja tetapi santri terlebih dahulu memahami dan mengetahui hukum ilmu tajwid dan mudah melafaskannya (Wawancara santri pondok tahfidz Al-birr Malino).

Dari kesimpulan kedua wawancara diatas peneliti menyimpulkan bahwa sistem tahsin ini adalah perbaikan bacaan terlebih dahulu, setelah itu baru melangkah ketahap selanjutnya, bahkan hasil observasi peneliti sendiri, peneliti mengamati bagaimana santri dengan semangatnya luarbiasa dalam mengahafal Alquran disamping itu santri diberi kesempatan untuk mengeluarkan bakatnya masingmasing yaitu, pelatihan kultum setelah ba'da sholat agar kelak mereka bisa memamfaatkan apa yang mereka dapatkan bukan hanya sekedar menghafal Alquran tetapi mereka juga mampu berdakwah didepan masyarakat, disamping itu dengan suasana alam yang mendukung santri lebih bersemangat menghafal quran dan santri diberi kesempatan untuk bisa berlibur yaitu dengan mentaddaburi alam yang ada disekitarnya supaya mereka bisa menyegarkan hati dan perasaan tanpa adanya tekanan dari Pembina.

Tahsin dalam Islam mengandung makna tuntutan agar 
dalam membaca Alquran harus benar dan tepat sesuai dengan contohnya demi terjaganya orisinalsitas praktek tilawah sesuai dengan sunnah Rasulullah SAW. Tahsin juga menyempurnakan semua hal yang berkaitan dengan kesempurnaan pengucapan huruf-huruf alquran dari aspek sifat-sifatnya yang senantiasa melekat padanya dan menyempurnakan pengucapan hukum hubungan antara satu huruf dengan yang lainnya seperti idzhar, idgham, ikhfa, dan sebagainya.

Sebagaimana dalam firman Allah Subuhana wata'ala

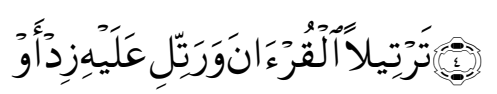

Terjemahnya :

Dan bacalah Alquran itu dengan perlahan-lahan (Q.S. Al Muzammil (73): 4).

Ayat ini jelas menunjukkan bahwa Allah Subuhana wata'ala memerintahkan Nabi Muhammad Shalallahu 'alaihi wassalam untuk membaca Alquran yang diturunkan kepadanya dengan tartil, dan itu menperindah pengucapan setiap hurufhurufnya (Bertajwid).

\section{Sistem Privat}

Sistem ini sama dengan tahsin yang tetapi terkhusus untuk pribadi yang secara rutin dilaksanakan.

Berdasarkan dari hasil wawancara yang peneliti lakukan oleh ustadz atau Pembina tahfidz selaku pimpinan pondok tahfidz Al-biir Malino ustadz Syarifuddin dan ustadz Arfan yang terkait dengan sistem privat mandiri bahwa: Sebelum dihafal Al-qur'an maka santri membaca kemudian Ustadz Mendengarkan dan memperbaiki bacaanya. Sistem ini hanya berlaku sekitar 2 bulan setelah ustadz melihat santri sudah bisa mandiri menghafal Qur'an maka santri melangkah pada sistem mandiri atau individual. (Wawancara ustadz Syarifuddin7 Juli 2016)

Dari pemaparan di atas maka, dapat ditarik kesimpualan bahwa sistem privat yaitu sebelum menghafal Alquran santri diharuskan membaca Alquran terlebih dahulu dihadapan guru/ustadz untuk perbaikan bacaan selama 2 bulan, setelah itu santri baru diperbolehkan melangkah pada sistem mandiri ketika sudah mengetahui hukum tajwid dalam menghafal Alquran, sedangkan sistem mandiri yaitu santri sudah ditargetkan menghafal quran 2 Juz/Bulan dengan Lancar dan tidak boleh menambah hafalan baru sebelum diujikan yang 2 Juz tersebut dengan sistem ujian baca semua dan ujian pertanyaan.

Belajar sistem privat dengan pengontrolan dari ustadz untuk perbaikan bacaan sebelum melangkah pada sistem mandiri bukan berarti belajar sendiri kesalahpahaman pengertian tersebut terjadi karena pada umumnya mereka sendiri tanpa Murabbi atau teman Ma'had Tahfidz Al-birr Malino. Belajar mandiri seperti halnya menghafal Alquran tanpa bantuan orang lain, setelah mengetahui hukum tajwid dalam menghafal quran.

\section{Sistem Mandiri}

Sistem mandiri ini santri sudah ditargetkan menghafal Qur'an 2 Juz/Bulan dengan Lancar dan tidak boleh menambah hafalan baru sebelum diujikan yang 2 Juz tersebut dengan sistem ujian baca semua dan ujian pertanyaan.(Wawancara Ustadz Arfan 7 Juli 2016) 
Dalam pelaksanaannya, konsep dasar itu dikembangkan dengan menggunakan beberapa cara sebagai berikut:

1. Adanya target hafalan quran yang harus dicapai sebanyak 2 juz perbulan yang sesuai aturan yang disepakati Ma'had Tahfidz Albirr Malino.

2. Menghafalkan tsumun atau persedelapan (1/8) perlu diketahui bahwa setiap juz terbagi menjadi dua hizb (Bagian) setiap Hizb terbagi menjadi empat bagian jadi, setiap juz ada delapan bagian. Satu bagian tersebut dinamakan tsunum. Jika hal ini dilakukan, maka seseorang akan selesai menghafalkan Alquran selama 240 hari yaitu delapan tsunum dikalikan tiga puluh juz berarti kurang dari satu tahun. Jika target hafalanya setengah tsunum, berarti kurang dari satu tahun. Jika target hafalannya setengah tsunum, berarti dia baru selesai menghafal setelah 440 hari atau setahun lebih.

Menghafal beberapa ayat saja semisal tiga atau lima ayat. Jika hal ini dilakukan maka waktu selesai menghafal menjadi bertambah panjang.

\section{B. Faktor-faktor yang mendukung} dan menghambat sistem pembinaan halaqah dan kecerdasan emosional quetient di Markaz tahfizh Alquran Albirr

\section{Faktor Pendukung dalam Pembinaan Halaqah}

Berdasarkan dari hasil wawancara dan observasi, peneliti menyimpulkan bahwa salah satu pendukung pembinaan halaqah Tahfidz Albiir Malino yaitu, Orang yang menyampaikan dirasah yang selalu membimbing santri dalam memotivasi belajar serta mengajarkan alquran atau pelajaran, dan siapa yang menyampaikan pelajaran di hadapan murid-murid, dia adalah ustadz/ guru (Mudarris).

\section{Faktor Penghambat dalam Pembinaan Halaqah}

a. Umur

Berdasarkan hasil wawancara dengan ustadz Syarifuddin salah satu pembina tahfdz bahwa: Umur atau usia adalah satuan waktu yang mengukur waktu keberadaan suatu benda atau makhluk, baik yang hidup maupun yang mati Semisal, umur manusia dikatakan lima belas tahun diukur sejak dia lahir hingga waktu umur itu dihitung dan belajar di usia muda bagaikan menulis di atas batu dan belajar di usia tua bagaikan menulis diatas air.

b. Lingkungan

Lingkungan merupakan faktor yang berpengaruh terhadap perkembangan anak. Salah satunya faktor lingkungan keluarga dan kita harus menanamkan komitmen dan berpegang teguh terhadap syariat Allah pada diri kita dan anak-anak agar mereka mengetahui dan membatasi diri dalam pergaulan antara sesama.

c. Kecanggihan Teknologi

Teknologi adalah terapan atau aplikasi dari ilmu yang dapat ditunjukkan dalam hasil nyata yang lebih canggih dan dapat mendorong manusia untuk berkembang lebih maju lagi.Namun, terlepas dari semua itu, perkembangan teknologi tidak 
boleh melepaskan diri dari nilainilai agama Islam.

\section{Pengaruh Sistem Pembinaan Halaqah terhadap Kecerdasan Emosional Santri di markaz Tahfizh Alquran Albirr}

a) Lingkungan keluarga.

Salah satu faktor yang mempengaruhi sistem pembinaan halaqah adalah faktor lingkungan dimana kecerdasan emosional quetient, hal ini akan menjadikan anak menjadi lebih mudah untuk menangani dan menenangkan diri dalam menghadapi permasalahan, sehingga anak-anak dapat berkonsentrasi dengan baik dan tidak memiliki banyak masalah tingkah laku seperti tingkah laku kasar dan negatif.

b) Lingkungan Masyarakat

Berdasarkan hasil wawancara di pondok Tahfidz Albiir Malino bahwa: lingkungan non keluarga dimana lingkungan masyarakat atau penduduk sangat berpengaruh dalam pergaulan mental anak/santri sebab karakter anak itu $40 \%$ saat dalam proses penciptaan (Alam Rahim) dan $40 \%$ saat masi kecil hingga $20 \%$ saat baligh dan hingga dewasa.

c) Kemauan dan Dorongan dari dalam

Kemauan atau dorongan dari dalam akan menyebabkan timbulnya kebulatan hati, jiwa tenaga bergerak mencapai suatu tujuan sehingga apa yang dicitacitakan oleh santri dapat terwujud dengan kemauan yang kuat dan bersungguh-sungguh dalam mengejar impian dalam menghafal Alquran, serta diawali dengan niat yang tulus karena segala sesuatu yang ingin kita lakukan semua berawal dengan niat dan yakin akan pertolongan dan kasih sayang Alla Swt.

d) Psikis

Psikis adalah jiwa manusia. Fisik dan psikis merupakan satu kesatuan yang seharusnya diselaraskan dalam setiap fungsinya. Namun kecerdasan emosi selain dipengaruhi oleh kepribadian individu, juga dapat dipupuk dan diperkuat dalam diri individu. Berdasarkan uraian tersebut dapat disimpulkan bahwa terdapat dua faktor yang dapat mempengaruhi kecerdasan emosi seseorang yaitu secara fisik dan psikis.Secara fisik terletak dibagian otak yaitu konteks dan sistem limbik, secara psikis diantarnya meliputi lingkungan keluarga dan lingkungan non keluarga.

\section{KESIMPULAN}

Berdasarkan uraian pada bab sebelumnya, maka pada bab ini peneliti mengemukakan kesimpulan mengenai sistem pembinaan halaqoh dan kecerdasan emosional queotient di markas tahfidz Alquran Albirr Malino kabupaten Gowa sebagai berikut:

1. Bentuk sistem pembinaan halaqah sangat baik dan terarah dalam pelaksanaannya dan santri lebih mudah memahami dengan sistem pembinaan ini, sebab jauh sebelumnya para ustadz/Pembina sudah memberikan gamabaran atau bimbingan mengenai sistem 
pembinaan halaqah sedangkan kecerdasan emosional queotient santri diberikan pemahaman bagaimana santri mampu memotivasi diri sendiri, bertahan menghadapi frustasi, mengendalikan dorongan hati, dan tidak melebih-lebihkan kesenangan, mengatur suasana hati dan menjaga agar beban stress tidak melumpuhkan, kemampuan berfikir serta berempati dan berdoa, dan sebisa mungkin memberikan kesempatan kepada santri untuk mengajukan pertanyaan hal-hal yang belum dimengerti terkait dengan sistem pembinaan halaqah dan kecerdasan emosional queotient.

2. Dalam hal proses pembinaan dan pengajaran tidak lepas dari kelebihan dan kekurangan para ustadz, dimana seorang ustadz/Pembina harus siap mengahadapi setiap santri yang berbeda karakter dan mampu mengarahkan kearah yang lebih baik serta tidak pernah lelah untuk selalu untuk selalu memberikan bimbingan dan ajaran kepada santri dalam menghafal Alquran, dan bisa menjadi panutan serta motivasi bagi santri.

3. Pengaruh sistem pembinaan halaqah dan kecerdasan emosional qouetien terhadap santri memberikan pengaruh positif terhadap peningkatan pemahaman santri mampu memotivasi diri, mengelola emosi, serta mampu mandiri dalam menghafal quran dengan baik setelah diberi bimbingan ilmu tajwid.

\section{DAFTAR PUSTAKA}

Al-Qur' anul Karim

Al Bukhari al-Ja'fi, Al-Bukhari, bin Hasyiati Sanadi, (Beirut: Dar al-Fikr, 1991), Jilid I.

Al-Quran dan Terjemah, Jakarta: Yayasan Penyelenggara Penerjemah Al-Quran, 1990.

AlHusna A Syalabi, 1988. Sejarah Pendidikan Islam, Terj. Prof. H. Muchtar yahya,Sanusi Latief Jakarta: Bulan bintang.

Agustian, Ary Ginanjar,2003ESQ Power Sebuah Inner Journey Melalui Al-Ihsan Jakarta: Arga.

Alder, Harry, Boost Your intelligence: Pacu EQ dan IQ and, terj. Christina Prianingsih ,Jakarta: Erlangga, 2001.

Firdaus, 1997. Ramayulis, Ilmu Pendidikan Islam, Jakarta: Kalam Mulia.

Goleman, Daniel, 2004. Emotional Intelligence atau Kecerdasan Emosional MengapaEI lebih penting daripada IQ, Terj. T. Hermaya, Jakarta: GramediaPustaka Utama cet. XIV.

Langgulung Hasan, 2002. Pendidikan islam mengahdapi Abad ke-21, Jakarta:Pustaka.

Haikal, 1973.Sejarah Hidup Muhammad, terjemahan Ali Audah, Jakarta: Tinta Mas, Jilid I. 
Yunus Mahmud, 1992. Sejarah Pendidikan Islam, Jakarta: PT. Hidakarya Agung.

Murodi, 2009.Sejarah Kebudayaan Islam, Semarang: Karya Toha.

Nisar Samsul. 2007. Sejarah Pendidikan Islam (Menelusuri jejak sejarah pendidikan Era Rasulullah Sampai Indonesia)Jakarta : Kencana.

Lubis Satria Hadi. 2010. Menggairahkan Perjalanan, Halaqah kiat agar halaqah lebih dahsyat full manfaat.Yogyakarta.Penerbit Pro-U Media.

Nawi syahruddin. 2014. Penelitian Hukum Normatif Versus Penelitian Hukum Empiris. Penerbit PT Umitoha Ukhuwah Grafika, Makassar.

Zuhairini, dkk, 2008.Sejarah Pendidikan Islam,cet.9, Jakarta: Bumi Aksara, , 